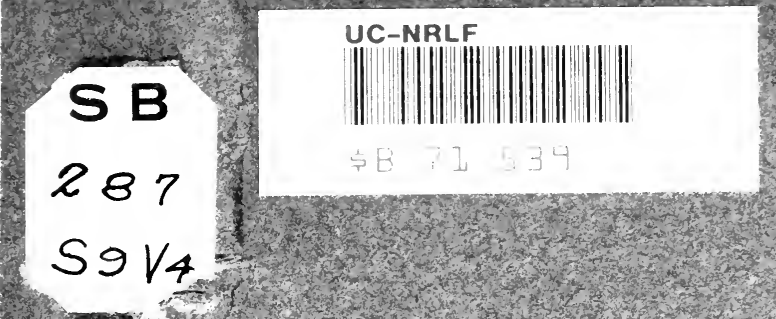

है

Q1 00

$\sqrt{a}$

10 


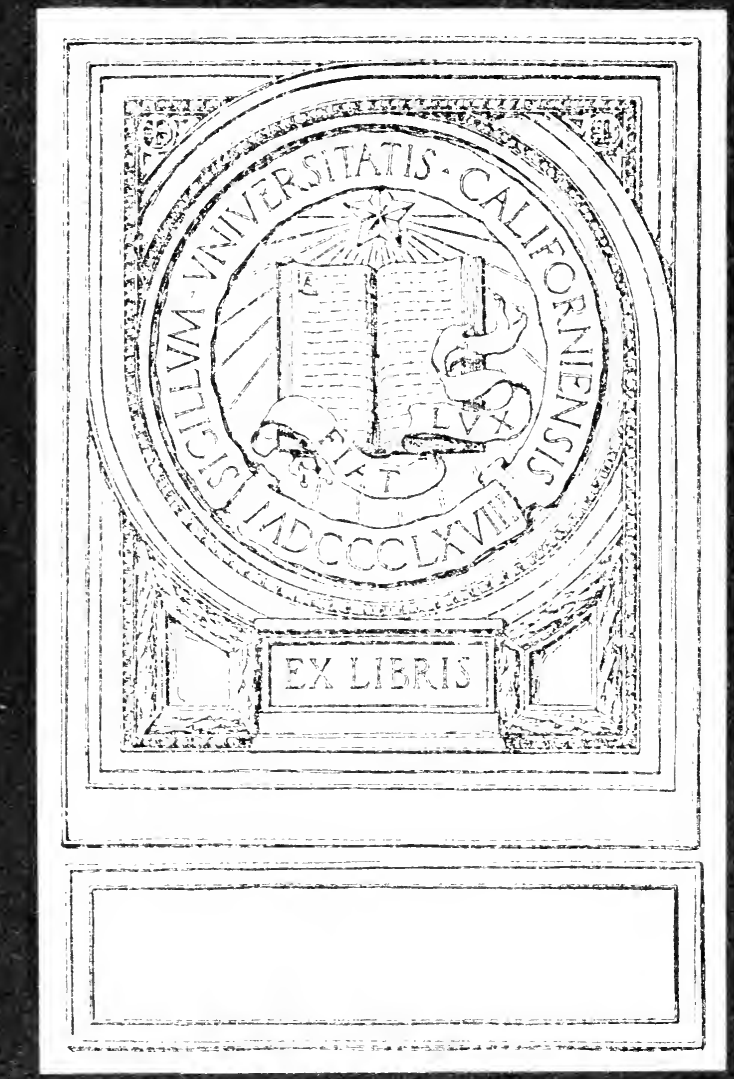




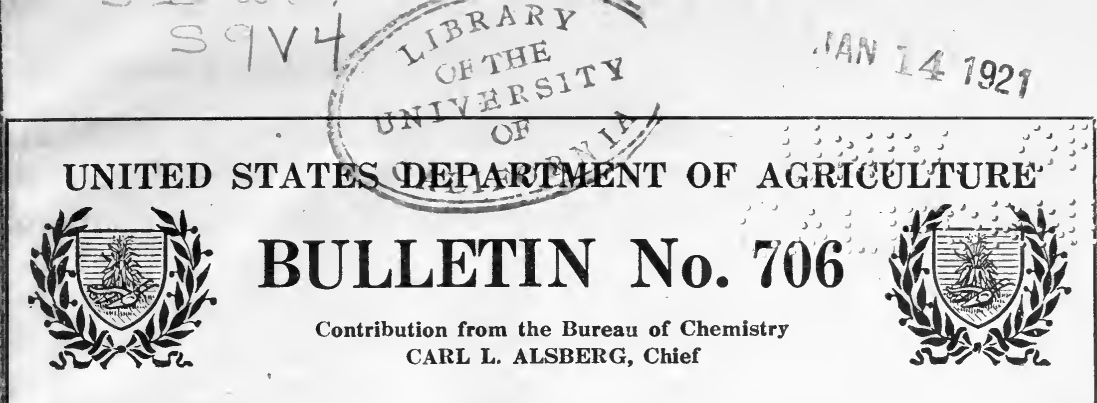

Washington, D. C.

Issued July 26, 1918; Revised November 6, 1920.

\section{AMERICAN SUMAC: A VALUABLE TANNING MATERIAL AND DYESTUFF.}

By F. P. Veitcin, Chemist in Charge, J. S. Rogers and R. W. Frey, Assistant $11 \quad$ Chemists, Leather and Paper Laboratory.

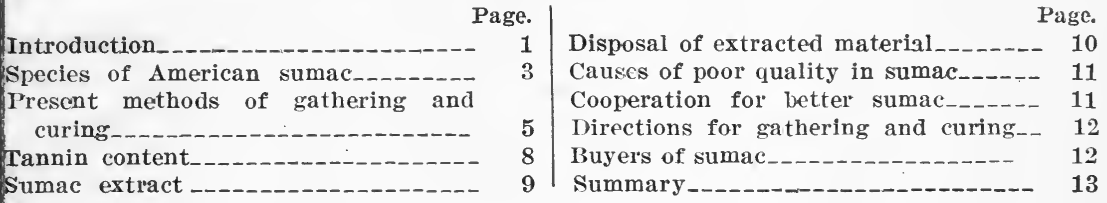

\section{INTRODUCTION.}

Sumac, known also as "shumac" or "shoemake," is a wild plant rich in tannin, a product of value to the tanning and dyeing industries. Sumac grows on uncultivated lands in many parts of the United States and is particularly abundant and accessible east of the Mississippi. Plentiful stands occur on cut-over land, in old fields and pastures, on mountain sides, in waste places, and on the edge of swamps in the Appalachian region. Immense quantities of this valuable tanning and dyeing material, which cost nothing to raise, remain ungathered every year, and are allowed to go to waste, while the United States imports annually more than $\$ 5,000,000^{1}$ worth of vegetable tanning materials.

Although there would seem to be little excuse for such an uneconomic condition, a study of the situation reveals certain obstacles in the way of making use of this sumac for the purposes to which it is adapted. It is hoped, however, that these difficulties may be overcome by the manufacturers and gatherers if they have a fuller realization of the possibilities of native sumac. The domestic sumac industry is well worth organization and development as a

${ }^{1}$ Foreign Commerce and Navigation of the United States, 1916, U. S. Department of Commerce. $3436^{\circ}-20$ 


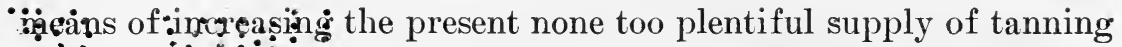
materials, of léseining our dependence on foreign countries, and of

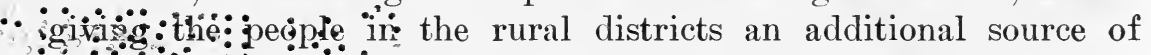
income.

Sumac leaves have long been used in tanning leather and in dyeing fabrics. The value of sumac for tanning depends chiefly upon the fact that it yields durable light-colored or white leathers, as a consequence of which it is employed largely in the tanning of bookbinding, glove, and hatband leathers, and for removing darker colored tanning materials from the surface of bag, case, and fair harness leathers. Sumac-tanned leathers have been found to be most durable and suitable for bookbindings and other purposes, where the leather must last indefinitely. The greater part of the gathered American sumac, however, is used in the dyeing of cotton goods.

The sumac industry in the United States is of direct interest to the country people of certain sections. It is largely a rural industry, since the sumac is harvested and cured by the country people and is sold through country dealers for grinding or for the manufactur? of extract.

In recent years the quantity of sumac gathered has been much smaller than formerly. Cheaper materials for making lightcolored leathers are in use, while the demands of dyers have not been large. American sumac, owing to careless gathering and curing, yields a darker colored leather than the sumac imported from Sicily, and, since sumac is used for tanning light-colored leathers, this quality renders the American product less desirable and decreases the demand for it. Another reason for the small amount collected is that the gatherers often earned less than could be made at other kinds of work.

While it is true that American sumac, if properly handled, will make an excellent substitute for Sicilian sumac, consumers of sumac must realize that the first step necessary for the production of a high-grade sumac similar to the foreign article is proper gathering and proper curing, which can be accomplished only by offering as an incentive a price commensurate with the labor and the quality of the product. The better the sumac the better should be the price. In this way mutual benefit will be gained and much will be done toward materially developing the domestic sumac industry.

Statistics probably do not indicate accurately the quantity of sumac gathered in the United States, because careful records are not kept by gatherers and dealers of the amounts collected and used. The figures for domestic production given in Table 1 were compiled from the Census reports, and the figures for the imports from the 
reporis on commerce and navigation of the United States, issued by the United States Department of Commerce.

TABLE 1.-Production of sumac in the United States.

\begin{tabular}{|c|c|c|c|c|}
\hline \multirow{2}{*}{ Year. } & \multicolumn{2}{|c|}{ Sumac extract. } & \multicolumn{2}{|c|}{ Ground sumac. } \\
\hline & Quantity. & Value. & Quantity. & Value. \\
\hline $\begin{array}{l}1899 \ldots . \\
1994 \ldots \\
1909 \ldots \\
1914 \ldots\end{array}$ & $\begin{array}{l}\text { Pounds. } \\
3,349,742 \\
4,093,619 \\
3,148,790 \\
4,512,361\end{array}$ & $\begin{array}{r}\$ 103,085 \\
95,958 \\
107,456 \\
129,631\end{array}$ & $\begin{array}{l}\text { Pounds. } \\
9,284,000 \\
5,061,333\end{array}$ & $\begin{array}{r}\$ 114,660 \\
65,190\end{array}$ \\
\hline & & & & \\
\hline
\end{tabular}

TABle 2.-Importation of sumac into the United States.

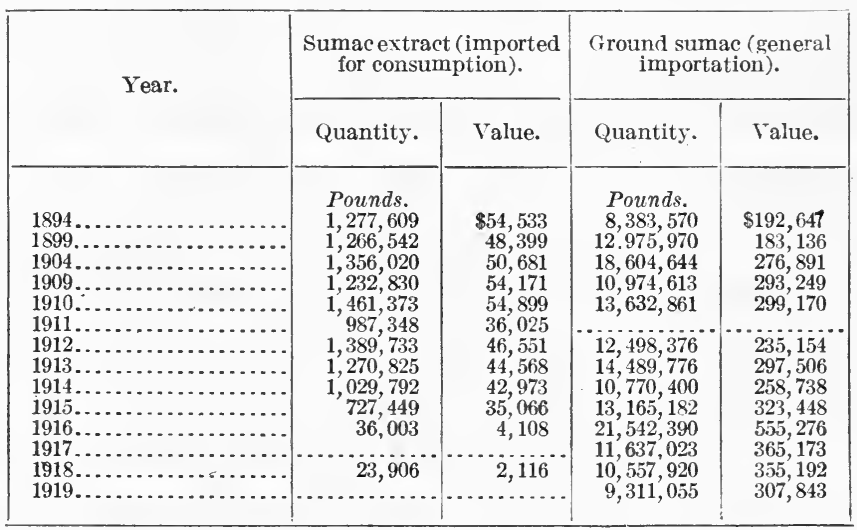

Information in the possession of the Bureau of Chemistry shows clearly that the consumption of domestic sumac during the two or three years prior to 1917 was more than $10,000,000$ pounds annually. Early in 1910 domestic sumac was quoted at $\$ 55$ a ton. In June, 1920 , Sicilian sumac was worth about $\$ 90$ a ton at the chief Atlantic ports, while domestic sumac was quoted at $\$ 75$ a ton.

\section{SPECIES OF AMERICAN SUMAC.}

Important species of sumac growing in North America are: Dwarf sumac (Rhus copallina L.), white sumac (Rhus glabra L.), and staghorn sumac (Rhus hirta (L.) Sudw.). Other species which contain tannin are: Fragrant sumac (Rhus aromatica Ait.), American smoke tree (Rhus cotinoides Nutt.), and coral or Jamaica sumac (Rhus metopium L.). Two species of sumac are poisonous, namely: Poison sumac, or poison elder (Rhus vernix L.), and poison or three-leaf ivy (Rhus radicans L.).

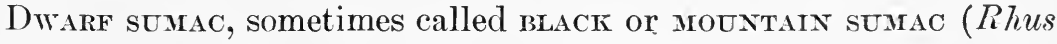
copallina).-A shrub or sometimes a small tree with maximum height 
of 30 feet and trunk diameter of 10 inches. The leaflets are dark green, smooth on top, paler and often hairy underneath, with edges smooth or few-toothed toward the apex. The fruit grows in dense terminal clusters, is crimson in color, and is covered with fine hairs. The unmistakable characteristics of this species are the winged growth along the leaf stem between the leaflets (PI. II, A) and the black specks on the new stalk. Dwarf sumac grows in dry soil, and may be found from Maine and southern Ontario to Florida and Texas, and west to Minnesota and Nebraska.

White sumac, sometimes called sMooth, upland, or scarlet SUMac (Rhus glabra).-A shrub, or rarely a small tree, 2 to 20 feet high. The leaflets are dark green on top and whitish underneath, with edges sharply saw-toothed. The fruit grows in dense terminal clusters, and is covered with short reddish hairs. The distinguishing characteristics of this species are the smoothness of the stalks and leaf stems, together with a bluish white bloom, a powdery film similar in appearance to that found on plums, which covers the stalks and the under side of the leaflets (Pl. III). White sumac grows in dry soil from Nova Scotia to British Columbia, and south to Florida, Mississippi, and Arizona.

Staghorn sumac, sometimes called HaIRY sumad (Rhus hirta).A shrub, or small tree, with maximum height of 40 feet and trunk diameter of 9 inches. Leaflets, dark green and nearly smooth on top, pale, and more or less hairy underneath, with edges sharply saw-toothed. The fruit, which grows in dense terminal clusters, is thickly covered with bright-crimson hairs. The distinguishing characteristic of this species is the hairy growth along the stalks and leaf stems (Pl. IV). Staghorn sumac is found in dry and rocky soils from Nova Scotia to Georgia, especially among the mountains, and as far west as southern Ontario, Minnesota, Missouri, and Mississippi.

Since poison sumac sometimes is mistaken for the more common species, and its poisonous effects are usually very severe, it seems desirable to describe it as an aid in distinguishing poison sumac from the other species.

Poison sumac, sometimes called PoIson ELDER (Rhus vernix).A shrub, or small tree, with maximum height of 28 feet and trunk diameter of 6 inches. The leaflets are green on top and underneath, with edges smooth. The fruit, which grows in loose, open clusters, consists of smooth white or light gray berries. It should be noted that poison sumac differs decidedly from the important species in the color and cluster formation of its fruit. Furthermore, it may be easily distinguished from the dwarf sumac by the absence of the winged growth along the leaf stems, and from the white and staghorn sumac by its smooth-edged leaflets (Pl. V). Poison sumac almost invariably is found in swamps. It grows from southern 
Ontario and near the eastern coast in the Eastern and Middle States, south to Florida, and west to Minnesota, Missouri, and Louisiana.

\section{PRESENT METHODS OF GATHERING AND CURING.}

\section{COMMON NAMES USED BY GATHERERS.}

Sumac is commonly termed by the gatherers either "black" or "white." "Black" sumac refers to dwarf sumac (Rhus copallina), and "white" sumac usually means white sumac (Rhus glabra), although it is believed that this term is sometimes applied also to staghorn sumac (Rhus hirta). Staghorn is not so extensively gathered as white sumac. In some sections, as in eastern Virginia, only black sumac is collected, while in others, such as the western part of Virginia and in West Virginia, Maryland, and Pennsylvania, small quantities of white sumac also are gathered.

\section{KINDS AND CONDITION OF SUMAC DESIRED BY EXTRACT MANUFACTURERS.}

Dwarf, or black, sumac is the only variety desired by extract makers, other species being refused because, it is stated, they contain a much higher proportion of pithy, milky stalks, and yield less extract. All contracts with gatherers specify that the sumac shall be dwarf, or black, only. The leaves and stems of the sumac alone are of value. The stalk is useless. While small, short new-growth stalks, broken off close below the leaf stem, may be accepted by the buyer, the chances are that they will be refused or received at a reduction in price. Gatherers are advised to take particular pains to see that their sumac contains very little stalk and no berries. Berries are of no value to extract makers.

PROPER TIME TO GATHER.

Extract makers are opposed to the early gathering of sumac, even though the leaves apparently are mature. They state that the leaves gathered in May and June are light in weight, do not yield as much extract, and can not be handled as well in the extracting process. From the viewpoint of both gatherers and extract makers, the best time to gather sumac is in July, August, and September. Gathering should not be done after frost, as the leaves then drop off readily and the color of the extract made from red leaves is darker and less desirable than that made from light-colored, well-cured leaves.

YIELDS PER ACRE.

While sumac is very plentiful, especially in the eastern United States, it rarely covers thickly an area of any extent, but, intermingled with other regetation, grows rather scattered in patches 
along old fence rows, and on cut-over and burned-over woodland. Reports have been received that in certain sections it grows thickly, unmixed with other growth, and in sufficient areas to permit cutting with a mowing machine. Several cases of clean stand have been reported, but they have not come directly to the attention of the Bureau of Chemistry. A report has been received from eastern Virginia of a tract of from 10 to 15 acres of burned-over and cut-over land from which 5 tons of dwarf sumac (leaves, leaf stems, and current year's stalk) were gathered. An estimate by the bureau, based on white sumac gathered from a plot 20 by 30 feet, gave a calculated yield per acre of 4,864 pounds (green weight). This would make about 1,600 pounds of cured sumac.

\section{QUANTITY A MAN CAN GATHER IN ONE DAY.}

Many factors may influence the quantity a man can gather. Some of these are the experience and alacrity of the gatherer, availability or lack of teams for hauling, growth of sumac-whether dense or scattering-species of sumac collected, and whether leaves, leaf stems, and stalks, or only leaves and leaf stems are gathered. The sumac collected by one man in one day may weigh from 150 to 600 pounds when tried, but averages between 200 and 300 pounds. From experiments conducted by the bureau, in which the sumac was collected by an experienced gatherer, it has been estimated that the following amounts of sumac (leaves, leaf stems, and stalk combined) can be gathered in one eight-hour day by an energetic man, provided the stand is good, so that little time is lost in going from one patch to another:

Dwarf, 728 pounds green; loss of water in curing, 54 per cent; cured sumac, 335 pounds. ${ }^{1}$

White, 1,744 pounds green; loss of water in curing, 67 per cent; cured sumac. 576 pounds.

Staghorn, 952 pounds green ; loss of water in curing, 58 per cent ; cured sumac, 400 pounds.

Where the stand is scattering or the gatherer is slow, the quantity gathered will be less, but in no case should an able-bodied man be satisfied with less than 200 pounds of cured sumac (leaves and stalks) from his day's work.

In those sections where black, or dwarf, sumac grows plentifully, exceptionally high wages can be earned, particularly by women, children, and the older men, by gathering sumac. Spare time during July and August, which usually is a comparatively inactive period on the farm in the sumac-growing sections, can be profitably employed in this way. By gathering and carefully curing sumac, at $\$ 1$

1 The dwarf sumac was more scattered than the other two varieties. This may account for the comparatively low figures for this species. 
per hundred pounds, any active gatherer can make from $\$ 2$ to $\$ 2$ a day, while at $\$ 2$ per hundred pounds he can earn from $\$ 4$ to $\$ 6$ a day.

\section{GATHERING AND CURING.}

The general practice followed in gathering is to break or cut (only the black can be broken readily) the new-growth stalk just below the lowest leaf stem. Sumac never should be allowed to wilt in the sun for more than a lew hours. It should be hauled to a barn and spread on the clean floor in a layer from 1 to 3 feet deep, or on racks which permit the circulation of air underneath. The sumac must be turned once or twice each day for a week, to aid in the drying and to prevent the leaves from molding. The brightest sumac is not allowed to wilt in the sun, but is spread at once on racks in the barn or under cover. This method aids materially in producing sumac of the lightest and best color.

\section{LOSS IN CURING AND HANDLING.}

Experienced gatherers estimate that 100 pounds of green sumac makes only from 40 to 50 pounds of the cured sumac. There is still further loss in weight between the time of purchase by the dealer and the time of sale, due largely to loss of moisture, still present because of incomplete drying, to falling of leaves, and to the removal of adhering dirt. This loss between the purchase and sale by the dealer varies in amount from 5 to 15 pounds, thus making a total loss in weight of from 60 to 75 pounds per hundred pounds of the original green sumac.

Results of laboratory experiments on the curing of sumac (leaves, leaf stems, and stalks), given in Table 3, show losses while curing which agree well with those estimated by gatherers.

TABLE 3.-Loss of moisture in curing sumac (collected september 28, 1916).

\begin{tabular}{|c|c|c|}
\hline Species. & $\begin{array}{l}\text { Duration } \\
\text { of drying. }\end{array}$ & $\begin{array}{c}\text { Loss of } \\
\text { moisture. }\end{array}$ \\
\hline Dwarf...... & $\begin{array}{r}\text { Days. } \\
5 \\
25 \\
49\end{array}$ & $\begin{array}{r}\text { Per cent. } \\
50.5 \\
53.2 \\
53.6\end{array}$ \\
\hline White................ & $\begin{array}{r}5 \\
25 \\
49\end{array}$ & $\begin{array}{r}63.9 \\
66.1 \\
66.6\end{array}$ \\
\hline Staghorn.. & $\begin{array}{r}5 \\
25 \\
49\end{array}$ & $\begin{array}{l}55.5 \\
57.3 \\
57.8\end{array}$ \\
\hline
\end{tabular}

There is reason to believe that the loss in curing on the farm is not so great as the loss observed in the bureau's experiments, where the sumac dried out very thoroughly. 
PREPARATION FOR TRANSPORTATION.

Sumac received by the dealers from the farmers usually comes in bags, or is handled leose in wagonloads like hay, and in many instances may have been hauled as far as 20 miles. Many farmers prefer to deliver the sumac in wagonloads, as they claim that too much time is consumed by putting it up in bags. Since the sumac becomes very brittle when dried and the leaflets are easily broken from the leaf stems, much loss occurs in handling it loose, and the gatherer can make more by bagging his sumac, packing each bag as full as possible. These bags cost the dealers 8 to 9 cents each, but are usually furnished without cost to the gatherers. Some gatherers, after drying the sumac, flail off the leaves and pack them in bags for shipment. Seventy-five pounds should be packed into a 4-bushel bag.

From the small dealers to the extract manufacturers the sumac is usually handled in bags or bales. The cost of baling is about 10 cents per hundrerlweight.

\section{PRICES PAID GATHERERS AND DEALERS.}

During the seasons of 1918 and 1919 in eastern Virginia the gatherers received from $\$ 1.25$ to $\$ 1.50$ per 100 pounds in trade from the dealers. The extract manufacturers furnished bags for use in hauling and shipping the cured sumac. The extract makers paid $\$ 1.65$ per 100 pounds for the bagged material, which in this region includes some new-growth stalks as well as the leaves and leaf stems. In 1919 in northern West Virginia and western Maryland the gatherers received $\$ 1.50$ per hundred pounds in trade from the dealers. In 1920 , the price rose to $\$ 2.00$ per hundred pounds at the shipping point.

\section{TANNIN CONTENT.}

The leares and leaf stems together of the three most important American sumacs-dwarf, white, and staghorn-when air-dried contain approximately the same quanity of tannin-that is, from 20 to 35 per cent. ${ }^{1}$ The leaves of fragrant sumac are said to contain 13 per cent tannin, those of American smoke-tree 21 per cent, and those of coral sumac 8 per cent. Usually the quantity of tannin appears to be somewhat greater later in the season than in June and early July. The leaves contain the highest percentage of tannin after they are fully grown and before they begin to turn yellow or red.

Analyses made in the Leather and Paper Laboratory of the Bureau of Chemistry of various samples of sumac gathered in Virginia, West Virginia, Maryland, and Pennsylvania gave the results shown in Table 4.

\footnotetext{
${ }_{1}^{1}$ These figures apply more particularly to Virginia, West Virginia, Maryland, and Pennsylvania sumacs.
} 


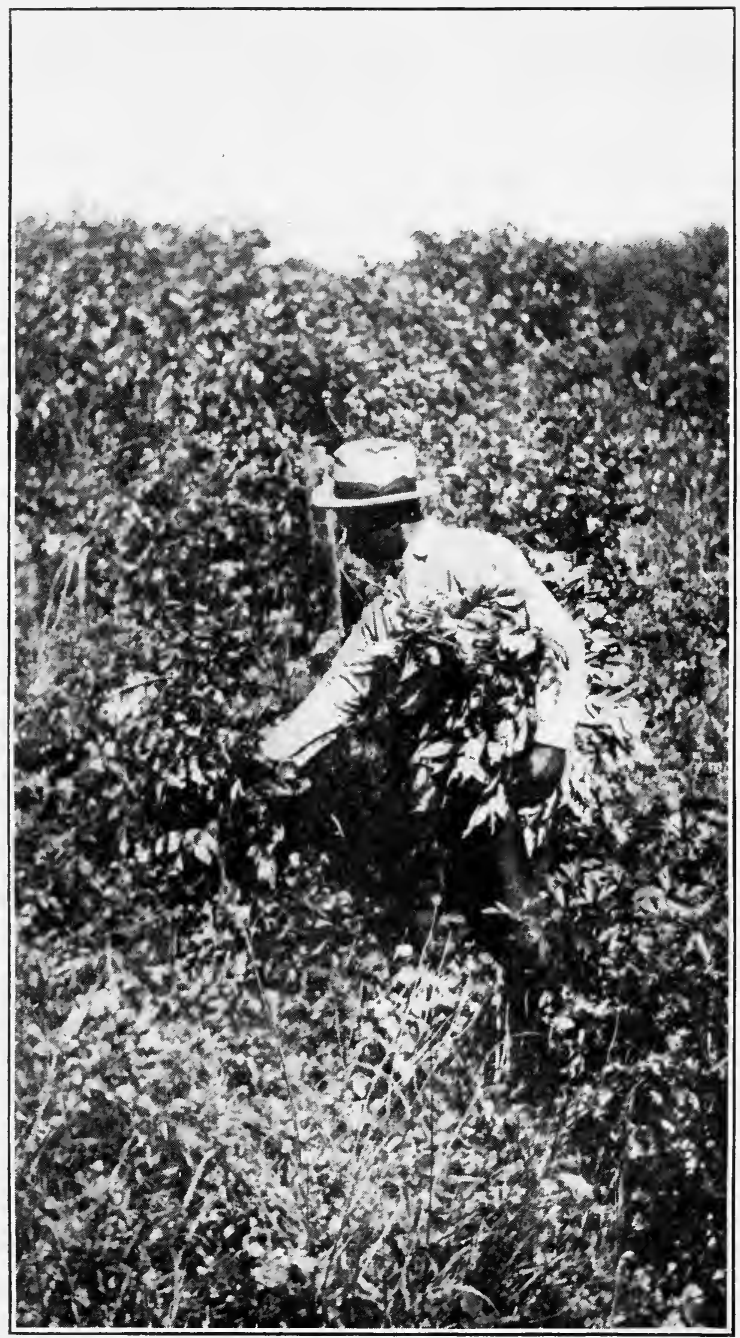

GATHERING DWARF SUMAC, THE ONLY KIND SUMAC DEALERS WANT. 


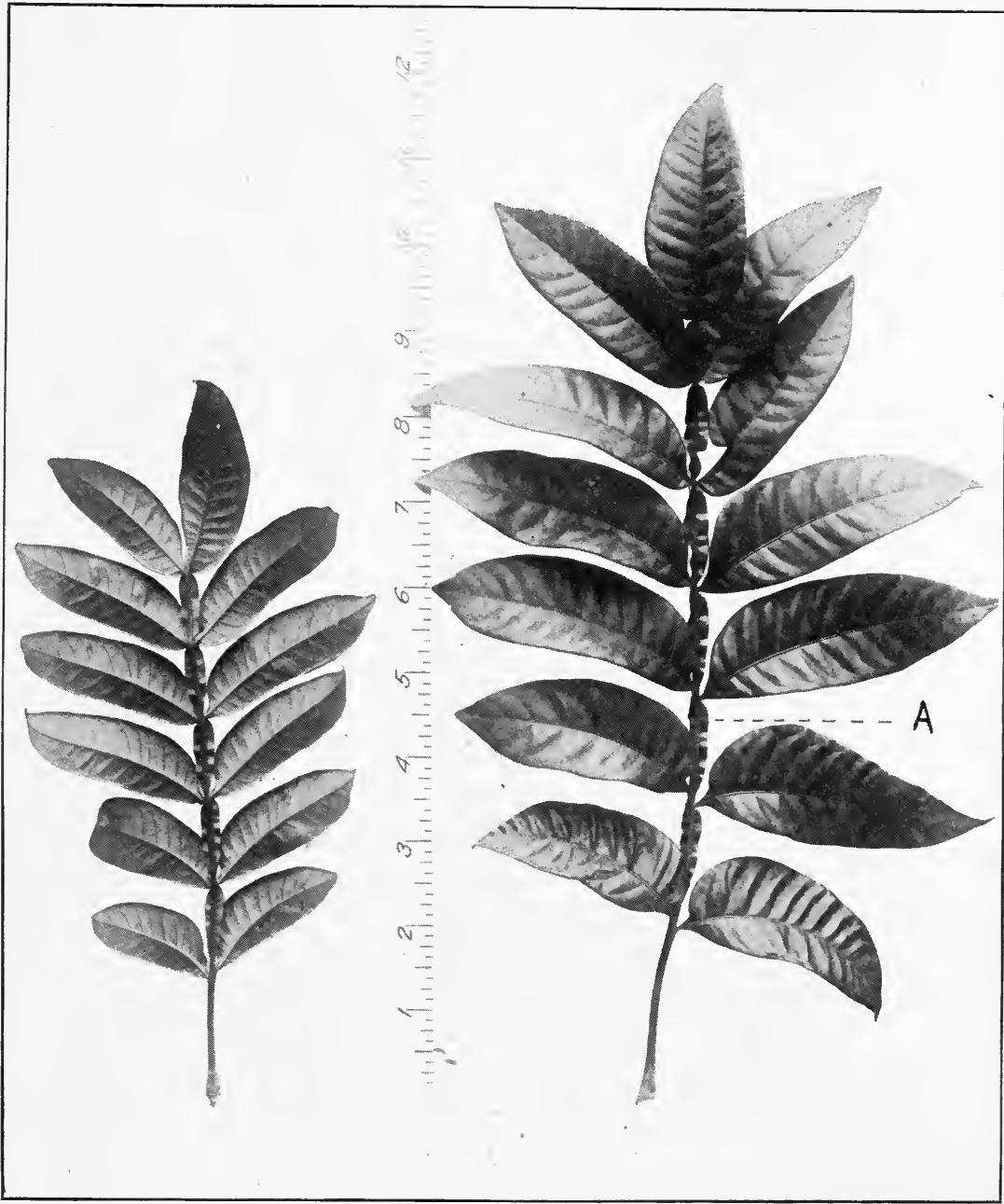

DWARF SUMAC LEAVES AND LEAF STEMS.

This is the only part of bush that is of value to the extract maker. The gatherer should receive from 35 to 45 per cent more for the leaves and leaf stems than for the leaves, leaf stems, and stalks. Note the peculiar growth along the leaf stems which is characteristic of dwarf sumac. 
Bul. 706, U. S. Dept. of Agriculture.

Plate $\mathrm{I} / \mathrm{l}$.

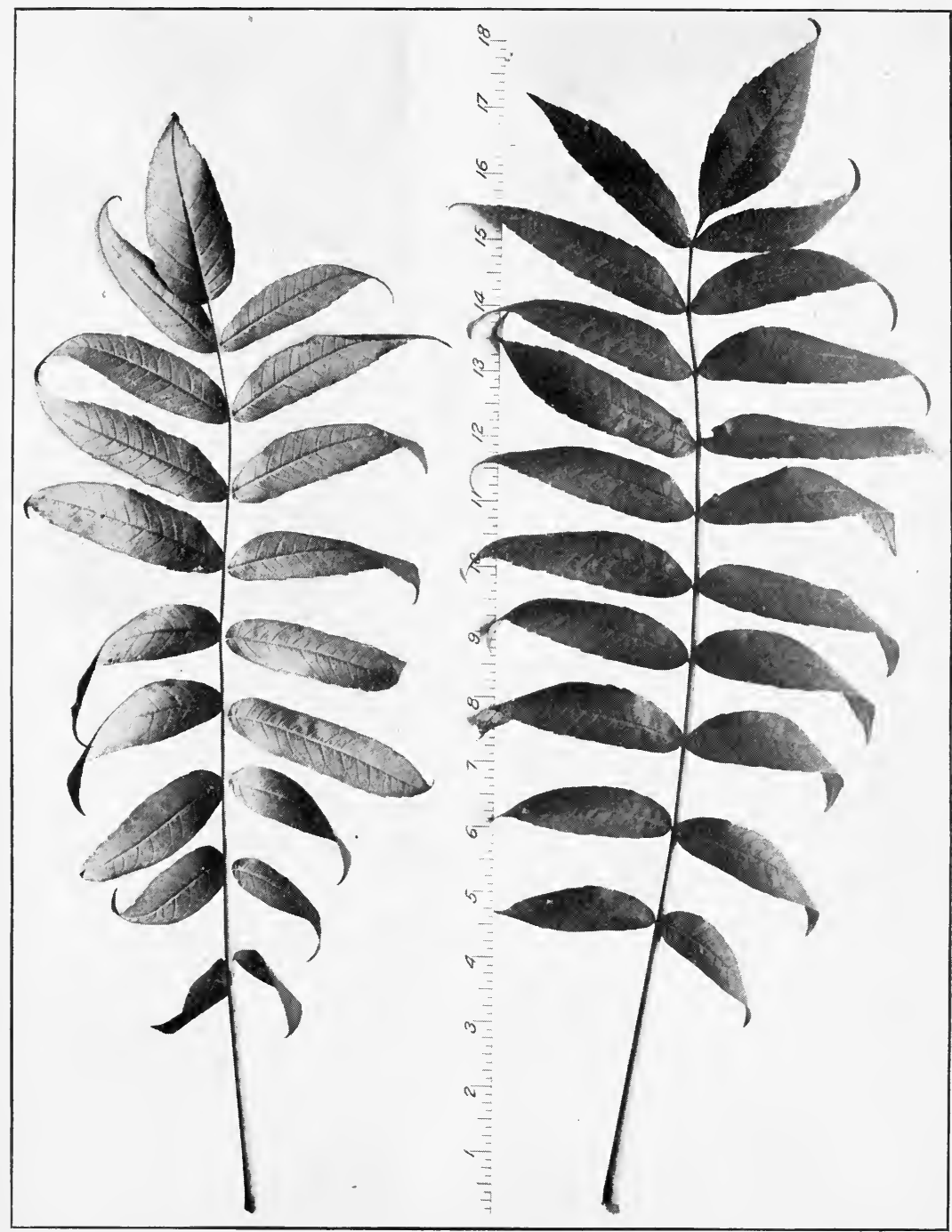

White Sumac Leaves and Leaf Stems. 


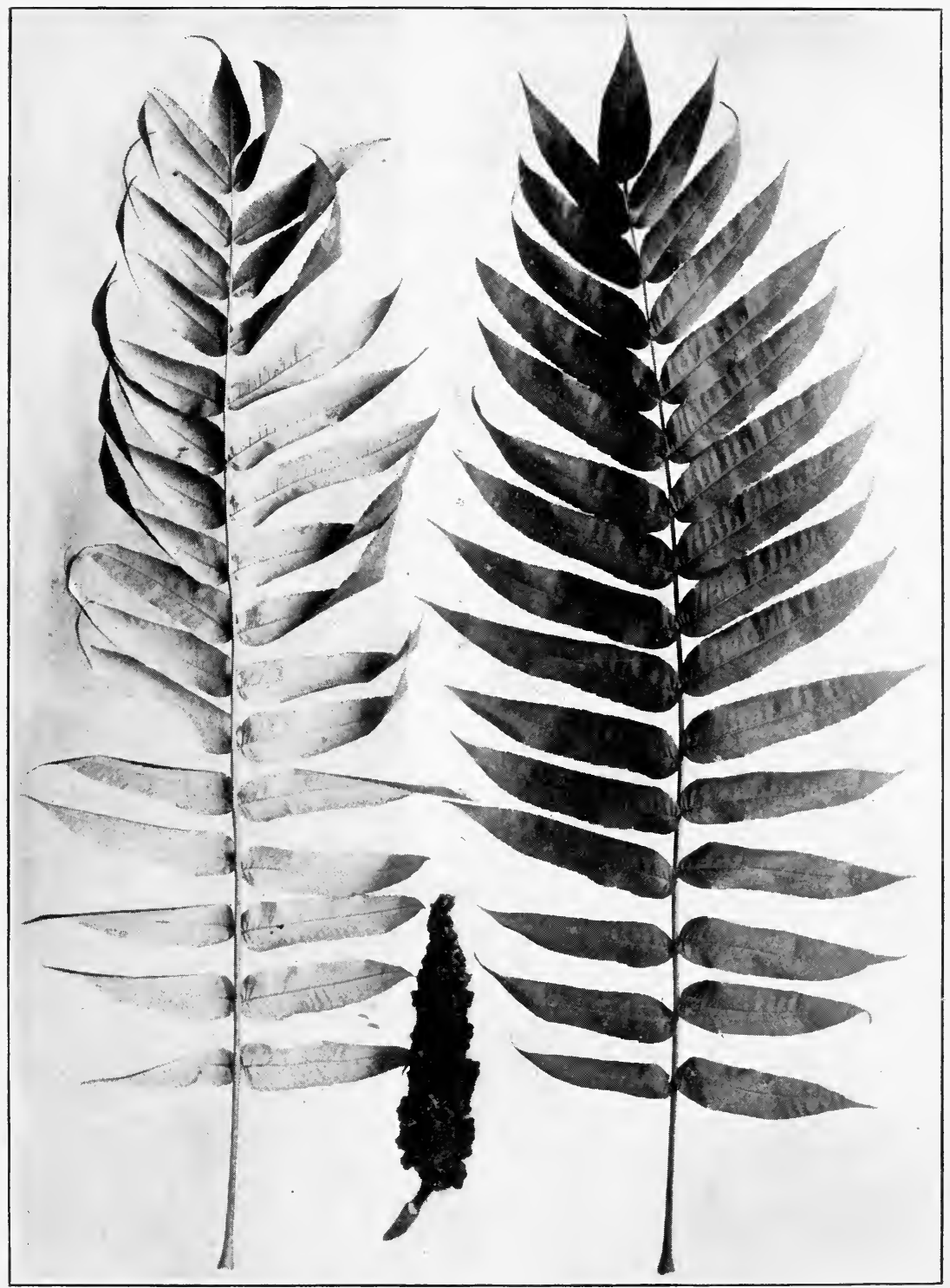

STAGHORN SUMAC LEAVES AND LEAF STEMS. 


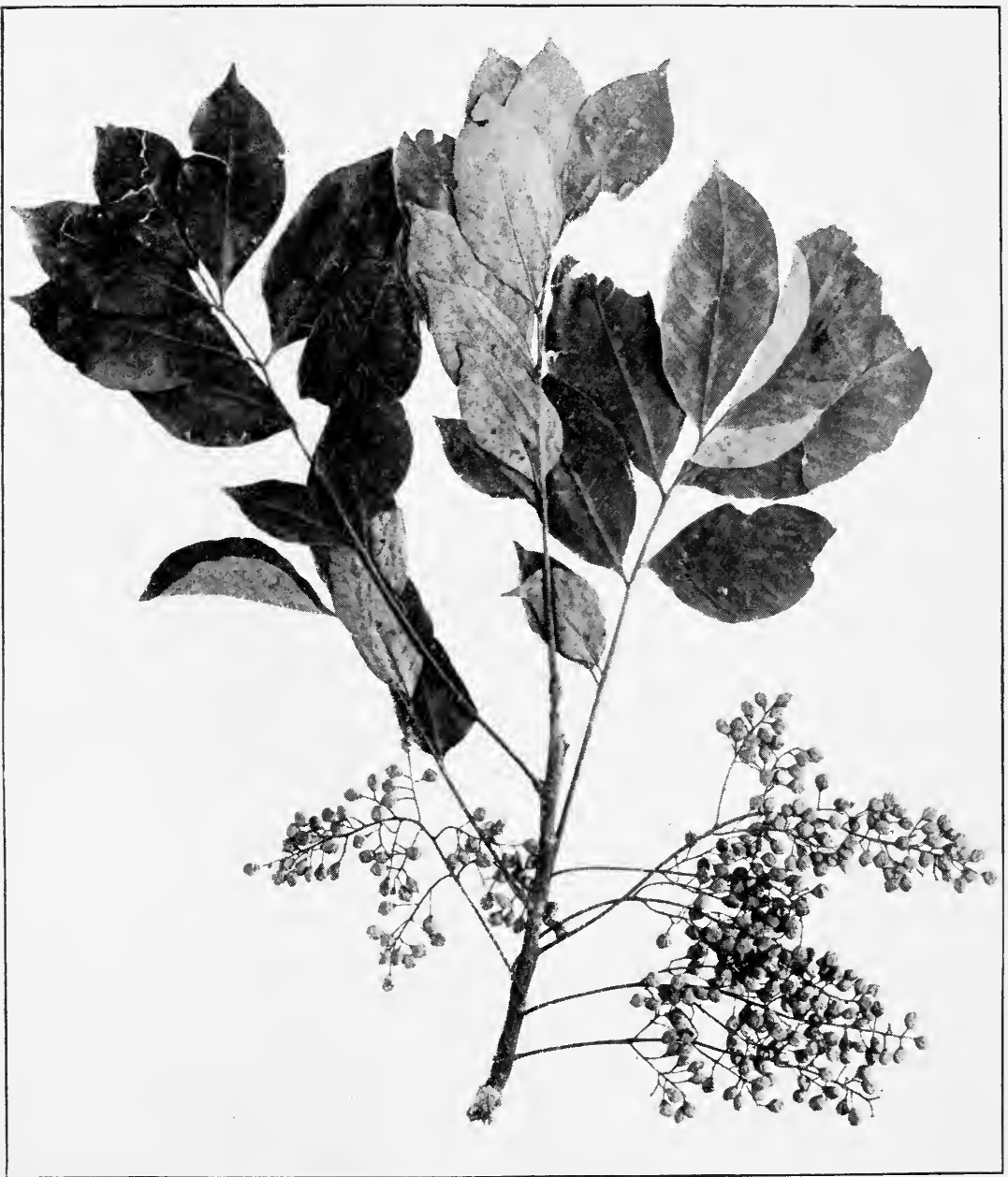

POISON SUMAC.

Do Not Gather ThIS KIND. 

TABLE 4.-Tannin content of samples of dwarf, white, and staghorn sumac.

\begin{tabular}{|c|c|c|c|c|c|c|c|}
\hline \multirow{2}{*}{ Species. } & \multirow[b]{2}{*}{ - } & \multicolumn{3}{|c|}{$\begin{array}{l}\text { Tannin in leaves and leaf } \\
\text { stems. }\end{array}$} & \multicolumn{3}{|c|}{ Tannin in stalks. } \\
\hline & & Average. & $\begin{array}{l}\text { Maxi- } \\
\text { mum. }\end{array}$ & $\begin{array}{l}\text { Mini- } \\
\text { mum. }\end{array}$ & Average. & $\begin{array}{l}\text { Maxi- } \\
\text { mum. }\end{array}$ & $\begin{array}{l}\text { Mini- } \\
\text { mum. }\end{array}$ \\
\hline $\begin{array}{l}\text { Dwarf............. } \\
\text { White............ } \\
\text { Staghorn....... }\end{array}$ & & $\begin{array}{r}\text { Per cent. } \\
28.95 \\
25.41 \\
27.66\end{array}$ & $\begin{array}{r}\text { Per cent. } \\
35.03 \\
28.08 \\
30.59\end{array}$ & $\begin{array}{r}\text { Per cent. } \\
19.46 \\
21.35 \\
21.53\end{array}$ & $\begin{array}{r}\text { Per cent. } \\
7.77 \\
6.84 \\
7.07\end{array}$ & $\begin{array}{r}\text { Per cent. } \\
9.94 \\
7.30 \\
8.09\end{array}$ & $\begin{array}{r}\text { Per cent. } \\
5.09 \\
6.19 \\
6.45\end{array}$ \\
\hline
\end{tabular}

Dwarf sumac, it will be seen, contains somewhat more tannin than staghorn or white sumac. This bears out in a general way the statement of buyers in eastern Virginia, though this difference is of itself not great enough to justify the refusal of the white. The sumac samples analyzed were found to average 73.3 per cent leaves and leaf stems and 26.7 per cent stalks. The variation, however, was marked, extending, in the case of the leaves and leaf stems, from 54 to 89 per cent, and, for the stalks, from 11 to 46 per cent. The large proportion of stalks indicated by the percentage last given should never be permitted. Gatherers must break the stalk close up to the lowest leaf stem, and must not gather the long stalk bare of leaves. If the stalks are broken close to the leaf stems, the sumac will usually meet the buyers' demands. Dealers and extract makers should insist that the sumac delivered shall not have more than 25 per cent of stalks.

The portions of the plant usually considered of value for tanning and dyeing purposes are the leaves and leaf stems, although, as shown in Table 4, the stalks contain from 5 to 10 per cent tannin, an amount entirely too large to discard after the trouble and expense of collecting and hauling to market has been incurred. This tannin should be recovered, as an extract could be made from the stalks and off-colored leaves that would be satisfactory for tanning and dyeing purposes when color is not the primary consideration.

\section{SUMAC EXTRACT.}

It has been the experience of sumac extract makers that sumac from Virginia, West Virginia, North Carolina, and western Kentucky contains the most tannin and yields more extract than that from the States farther north. For that reason, they prefer to buy their sumac from those southern States.

Formerly the users of domestic sumac bought the leaves or ground sumac, which is the sumac leaf ground to a coarse powder, and made their own liquors for tanning or dyeing from these materials. Recently the grinding of sumac has decreased, and users have bought sumac extract instead. The price of domestic sumac extract, which 
contains usually from 22 to 24 per cent of tannin and is sold on the basis of its strength, has increased materially in the past few years. For $42^{\circ}$ extract the quoted price a pound was: In 1914, about $3 \frac{3}{4}$ cents; in 1915, from $3 \frac{3}{4}$ to 9 cents; in 1916 , from $5 \frac{1}{2}$ to 10 cents; in 1917, from $4 \frac{1}{2}$ to 5 cents; in 1918, from $4 \frac{1}{2}$ to 5 cents; and in August, 1920 , from 7 to 8 cents.

A pound of extract contains approximately the same amount of tannin as a pound of properly gathered and cured leaf. In making the extract the tannin is extracted with large quantities of water which must be evaporated in expensive copper pans under skilled supervision and at some expense for fuel. When the extract is to be used, as much or more water than was evaporated in making it is added to secure a tanning or dyeing solution of the desïred strength. The consumer, however, often prefers to use the extract, rather than to make his cwn liquor from the leaf.

\section{DISPOSAL OF EXTRACTED MATERIAL.}

So far as can be learned, no really satisfactory method of disposing of the extracted leaves is in general use. The material is placed in large piles or ricks, or taken to fill in waste places. A small quantity is used on farm land as a top-dressing to be plowed under. Analyses of the commercially extracted material given in Table 5 show its fertilizing value.

TABLE 5.-Fertilizing value of commercially extracted sumac leaves and leaf steris and stalks.

\begin{tabular}{|c|c|c|c|c|c|c|c|c|c|}
\hline \multirow[b]{2}{*}{$\begin{array}{c}\text { Sample } \\
\text { No. }\end{array}$} & \multirow[b]{2}{*}{ Part of plant. } & \multirow[b]{2}{*}{$\begin{array}{l}\text { Mois- } \\
\text { ture. }\end{array}$} & \multirow[b]{2}{*}{$\begin{array}{c}\text { Cal- } \\
\text { ciumm } \\
\text { oxid. }\end{array}$} & \multirow[b]{2}{*}{$\begin{array}{l}\text { Potas- } \\
\text { sium } \\
\text { oxid. }\end{array}$} & \multirow[b]{2}{*}{$\begin{array}{l}\text { Phos- } \\
\text { phorus } \\
\text { pen- } \\
\text { toxid. }\end{array}$} & \multicolumn{4}{|c|}{ Ash. } \\
\hline & & & & & & Total. & $\begin{array}{l}\text { Cal- } \\
\text { cium } \\
\text { oxid. }\end{array}$ & $\begin{array}{l}\text { Potas- } \\
\text { sium } \\
\text { oxid. }\end{array}$ & $\begin{array}{l}\text { Phos- } \\
\text { phorus } \\
\text { pen- } \\
\text { toxid. }\end{array}$ \\
\hline 32479 & $\begin{array}{l}\text { Leaves and leaf } \\
\text { stems. }\end{array}$ & Per cent. & Per cent. & Per cent. & Per cent. & Per cent. & Pcr cent & Per cent. & Per cent. \\
\hline 3248 & do.................... & & 1.95 & .09 & .20 & 5.32 & 36.65 & 1.69 & $\begin{array}{l}3.76 \\
4.37\end{array}$ \\
\hline $\begin{array}{l}32479 \text {. } \\
32482 \text {. }\end{array}$ & $\begin{array}{l}\text { Stalks.... } \\
\text {....do... }\end{array}$ & $\begin{array}{l}4.59 \\
4.59\end{array}$ & $\begin{array}{l}1.31 \\
1.44\end{array}$ & $\begin{array}{l}.39 \\
.17\end{array}$ & $\begin{array}{l}.15 \\
.11\end{array}$ & $\begin{array}{l}3.43 \\
3.24\end{array}$ & $\begin{array}{l}38.19 \\
41.36\end{array}$ & $\begin{array}{r}11.37 \\
5.24\end{array}$ & $\begin{array}{r}4.37 \\
3.39\end{array}$ \\
\hline
\end{tabular}

Examination of a number of unextracted sumac samples gave: Ash, 4 to 7.5 per cent; potassium oxid, 1.18 to 2.15 per cent. The ash of these samples contained from 25 to 30 per cent of potassium oxid.

Comparison of the percentage of potassium oxid $\left(\mathrm{K}_{2} \mathrm{O}\right)$ in the original material and in the water extract, as obtained for the tannin analysis, shows that although the unextracted sumac contains rather high percentages of potassium oxid, this is almost entirely removed on extraction. These experiments were made on finely ground su- 
mac leaves and leaf stems, whereas in commercial practice the extraction generally is made on the unground leaves and stalks, and consequently is not so thorough, especially in the case of the larger stalks. This practice of making extraction on the unground leaves and stalks undoubtedly accounts for the comparatively high percentages of potassium oxid in the samples of commercially extracted stalks, analyses of which are given in Table 5 .

Except for the organic matter which it contains, extracted sumac has comparatively little value for the farmer. However, in sections where sumac is gathered, where the land is usually deficient in organic matter, the extracted material can be profitably hauled a mile or two, especially if before scattering on the land it can be mixed and rotted with barnyard manure.

\section{CAUSES OF POOR QUALITY IN SUMAC.}

Lack of care and attention to details in gathering and curing results in sumac of inferior quality. Undue exposure to the sun, any exposure to dew or rain, heating and molding in deep layers, and failure to turn once a day while curing cause decided darkening of the leaves and materially reduce the percentage of tannin. The presence of stalks, red leaves, blooms, or berries in cured sumac is objectionable, because they produce an undesirable color on leather. Furthermore, since the stalks contain only about one-fourth as much tannin as the leaves, their presence gives the mixture a lower tannin content. The presence of dirt or sand in cured sumac also is objectionable, for it increases the seight without increasing the tannin content, and leathers tanned with such sumac will darken because of the iron present.

\section{COOPERATION FOR BETTER SUMAC.}

One of the objects of this bulletin is to point out the necessity for helpful cooperation between gatherers, dealers, and extract makers, with a view to the production of higher grade sumac and sumac extracts and the payment of higher prices to the gatherers for better sumac. This cooperation can be successfully maintained only if it is mutually beneficial. The initiative and success rest with the final buyers, the extract makers, who, by offering a bonus for "extra" quality sumac, can encourage the gatherers to make special efforts to produce a high-grade, bright, clean product. It is suggested that, for the information and guidance of gatherers, dealers and buyers keep on hand suitable samples, one to be known as "Standard," for which they will pay the regular price, and another as "Extra," for which a bonus will be paid. Sumac materially below 
"Standard" in color or quality should be bought only at a reduction. If the directions for gathering and curing given in this bulletin are carefully followed, no sumac below "Standard" will be produced, while much of it will be of "Extra" quality.

\section{DIRECTIONS FOR GATHERING AND CURING.}

In order to obtain sumac of the best quality, both as to color and percentage of tannin, carefully follow these directions:

Gather only dwarf, or black sumac (Pl. II). Break the stalk bearing the leaves and leaf stems just below the lowest leaf stem; or, better, gather only the leaves and leaf stems, throwing away all blooms or berries. Harvest during July, August, and September. Do not collect red or yellow leaves. As soon as gathered, place the sumac in the shade or under a canvas cover, which permits the air to get to it, and prevents undue exposure to the sun. Do not allow it to be wet by dew or rain, and at the end of each day haul the gathered sumac to a barn or open shed, where it should be spread in layers not over $1 \frac{1}{2}$ feet deep upon a clean floor, or upon open racks which will permit ready access of air. Do not allow the gathered sumac to come in contact with the bare ground at any time, as dirt injures its quality. Turn the layers over once or twice daily for from one to two weeks, or until thoroughly dry. In case stalks have been gathered with the leaves, remove the stalks by flailing and forking out. The leaves thus prepared should be of a uniformly light-green color. Pack tightly in bags and keep in a well-aired, dry loft until sold.

\section{BUYERS OF SUMAC.}

Sumac, when properly cured, usually can be sold to merchants in towns or cities near the place where it has been gathered, or it can be sold directly to manufacturers who buy sumac for grinding or for the preparation of sumac extract. Before starting to gather, however, the gatherer should have a definite understanding and contract with the dealer as to the quantity which he will buy from him; the price which will be paid; how the sumac is to be delivered; arrangements for a supply of bags, if it is to be delivered in bags; and especially as to the extra price to be paid for exceptionally bright, wellcured sumac. If the names of dealers are not obtainable by inquiry of merchants, hide dealers, or others in near-by towns or cities, this information can be obtained from the various State agricultural experiment stations or from the Bureau of Chemistry. United States Department of Agriculture, Washington, D. C. 
SUMMARY.

Imported sumac is scarce and high priced. Domestic sumac, if properly gathered and cured, can be largely substituted for imported, and should bring better prices than domestic sumac as now cured. Sumac grows wild and abundantly on uncultivated lands, particularly on those east of the Mississippi River. Country people, especially the elderly, and women and children, can earn good wages from July to September by gathering and curing sumac.

Practically the only kind of sumac gathered in this country is dwarf, or black (Rhus copaltina).

Before beginning to gather, consult your local merchants or State experiment station to ascertain the names and addresses of buyers of sumac and of sumac extract makers. Be sure to arrange fully and clearly with the dealers as to: (1) The quantity which they will buy from you; (2) a supply of bags; (3) the price per hundred pounds; and especially (4) an extra price for well-cured sumac leaf.

In gathering, break the stalk close up to the leaf stem and do not include long bare stalks. Do not gather blooms, berries, or yellow or red leaves. Do not allow the gathered sumac to scald in the sun or to become wet with either dew or rain. Cure in the barn or under cover on a clean floor. Turn once or twice a day until the sumac is thoroughly dry and crisp. Pack and ship only in full, tightly packed bags. Do not bale, and do not allow dirt, stones, or pieces of iron to get into the bags. Such practices ultimately result in a loss to the gatherer.

As now prepared for the market, domestic sumac contains less tannin than and is greatly inferior in color to imported Sicilian sumac.

Proper gathering and curing will greatly improve the color of the domestic sumac leaf. Such leaf contains from 25 to 30 per cent of tannin, which is practically as much as the Sicilian leaf.

A pound of domestic sumac extract, of $42^{\circ}$ strength and containing from 22 to 24 per cent of tannin, was quoted in 1914 at about $3 \frac{3}{4}$ cents; in 1915 , from $3 \frac{3}{4}$ to 9 cents; in 1916 from $5 \frac{1}{2}$ to 10 cents; in 1917, from $4 \frac{1}{2}$ to 5 cents; in August, $1918,4 \frac{1}{2}$ to 5 cents; and in August, 1920, from 7 to 8 cents.

The development of the American sumac industry and the production of bright, uniformly and properly cured domestic sumac can be accomplished only through the earnest and whole-hearted cooperation of the extract makers, merchants, buyers, and gatherers. Extract makers and buyers must make every effort to stimulate the proper gathering and curing by offering better prices and through. careful instructions in proper methods of gathering, curing, and packing. The gatherers must help by following carefully the directions set forth in this bulletin and by working harmoniously with the buyers. 
ADDITIONAL COPIES

OF THLS PUBLICATION MAY BE PROCURED FROM THE SUPERINTENDENT OF DOCUMENTS GOVERNMENT PRINTING OFFICE

WASHINGTON, D. C.

$\mathrm{A}^{\mathrm{T}} \mathrm{T}$

5 CENTS PER COPY 




\section{$\therefore 2109$}

UNIVERSITY OF CALIFORNIA LIBRARY

$$
\text { Sing }
$$


